\title{
DERLEME
}

\section{Çölyak Hastalığı İle Tamamlayıcı Beslenme, Anne Sütü Ve Emzirme İlişkisi Hayriye YILDIRIM ${ }^{1}$, Hande ÖNGÜN YILMAZ ${ }^{2}$}

\section{$\ddot{\mathbf{O Z Z}}$}

Gluten Enteropatisi veya Çölyak Sprue olarak da bilinen Çölyak Hastalığı (ÇH), gluten içeren yiyeceklerle yaşamın ilk aylarındaki tamamlayıcı beslenme sürecinde tanışılması ile ortaya çıkan kronik otoimmün bir ince bağırsak hastalı̆̆ıdır. Çevresel etmen olan glutenin tetikleyici özelliğinin ortadan kaldırılması ile ömür boyu süren tıbbi beslenme tedavisi sonucunda tam düzelme sağlanabilmektedir. Az miktarda yulafta bulunmakla birlikte daha çok arpa, çavdar ve buğdaydaki bitkisel protein glutenin diyetten elimine edilmesi gereklidir. Hastalığı aktive etmeyen taneler ise mısır, pirinç ve ülkemizde karabuğday olarak bilinen greçkadır. Çölyak Hastalığı ile anne sütü, tamamlayıcı beslenme uygulamaları, glutene başlama yaşının etkisi ve emzirmenin koruyuculuğu üzerindeki tartışmalar devam etmektedir. Anne sütü ve emzirmenin klinik semptomların ortaya çıkışını önleyip önlemediği ya da geciktirip geciktirmediği; tamamlayıcı beslenme döneminde glutenle tanışma zamanlamasının veya gluten miktarının ne olması gerektiği ile ilgili konular halen çelişkilidir. Öte yandan Avrupa Pediatrik Gastroenteroloji, Hepatoloji ve Beslenme Birliği (ESPGHAN) tarafından tamamlayıcı beslenme dönemindeki glutenle tanışma zamanının erken ( $<4$ ay) ya da geç ( $\geq 7$ ay) olmaması gerektiği ve glutenin beslenme programına dahil edilirken emzirmenin de sürdürülmesi gerektiği vurgulanmaktadır. Bu yazıda tamamlayıcı beslenmenin ÇH semptomlarının başlangıcı üzerindeki etkisi ile anne sütü ve emzirme ilişkisine dair çalışmalar irdelenerek güncel literatürün derlenmesi hedeflenmiştir.

Anahtar Kelimeler: Anne sütü; Çölyak Hastalığı; Emzirme; Glutensiz Diyet

\section{The Relationship Between Celiac Disease and Complementary Feeding, Breast Milk and Breast- feeding}

\author{
Hayriye YILDIRIM ${ }^{1}$, Hande ÖNGÜN YILMAZ ${ }^{2}$
}

\begin{abstract}
Celiac Disease (CD), also known as Gluten Enteropathy or Celiac Sprue, is an autoimmune chronic intestinal disease that occurs when glutencontaining foods are introduced during the complementary feeding process in the first months of life. In order to eliminate the triggering feature of gluten, which is an environmental factor, a full recovery can be achieved as a result of the effect of lifelong medical nutrition therapy. Although there is a small amount of oats, the vegetable protein gluten in mostly barley, rye and wheat should be completely eliminated from the diet. The grains that do not activate the disease are corn, rice and greçka known as buckwheat in our country. Discussions continue on the effect of age at initiation of gluten and the protection of breast-feeding in breast milk and complementary feeding practices with Celiac Disease. There are still controversies regarding whether breast milk prevents or delays the emergence of clinical symptoms in CD, or whether the timing of gluten introduction and the amount of gluten should be during the complementary feeding period. On the other hand, it is emphasized by the European Association of Pediatric Gastroenterology, Hepatology and Nutrition (ESPGHAN) that the time to meet gluten in the complementary feeding period should not be early ( $<4$ months) or late ( $\geq 7$ months) and breast-feeding should be continued while gluten is included in the nutrition program. In this article, it is aimed to review the current literature by examining the effects of complementary feeding on the onset of symptoms and the relationship between breast milk and breast-feeding in Celiac Disease.
\end{abstract}

Keywords: Breast-feeding; Breast milk; Coeliac Disease; Gluten-Free Diet

${ }^{1}$ Marmara Üniversitesi Pendik Eğitim ve Araştırma Hastanesi, Beslenme ve Diyet Birimi, 34899, İstanbul, Türkiye

${ }^{2}$ İstanbul Okan Üniversitesi Sağlık Bilimleri Fakültesi, Beslenme ve Diyetetik Bölümü, 34959, İstanbul Türkiye Sorumlu Yazar: Hayriye YILDIRIM

E-posta adresi: hayriyemanav@gmail.com

ORCID No: 0000-0002-2403-3419

Gönderi Tarihi: 04.10 .2020

Kabul Tarihi: 08.09 .2021 


\section{GİRIŞ}

Çölyak Hastalığı (ÇH), Avrupa Pediatrik

Gastroenteroloji, Hepatoloji ve Beslenme Birliği’ne (ESPGHAN) göre kalıtımsal yatkınlığı olan bireylerde gluten ve ilişkili olduğu prolaminlerin sebebiyet verdiği immün aracılı sistemik bir bozukluk olarak tanımlanmaktadır. Glutene özgü klinik semptomların farklı kombinasyonlarının, gluten enteropatisine ait antikorların, insan lökosit antijeni HLA-DQ8 ve/veya HLA-DQ2 gibi haplotiplerin tespiti ile karakterize edilmektedir (1).

Çölyak Hastalığı Prevelans, Patogenez ve

\section{Etiyolojisi:}

Çölyak Hastalığı prevalansı, genel popülasyonda \%1-3 ve çölyak hastalarının birinci derece aile üyeleri arasında ise yaklaşık \%10'dur. Hastaların \%95'inden fazlas1, cis veya trans konfigürasyonunda HLA-DQ2 heterodimerine sahiptir (2). Hastalığa özgü antikor testleri kandaki TG2'ye (transglutaminaz Tip 2) karşı gelişen otoantikorları anti-TG2 veya EMA'y1 (endomisyal antikorlar) ölçer (1).

Buğday çekirdeği \%8-15 protein içerir ve bunun $\% 10-15$ 'i albümin ve globulin ve \%85-90'1 glutendir (3). Gluten, gluten enteropatisini tetiklemek için gereklidir. Glutene tolerans ile glutene karşı gelişen bağışıklık yanıtı arasındaki dengeyi düzenleyen genetik ve çevresel faktörler arasındaki etkileşim tam olarak anlaşılamamıştır. Gluten toleransından, glutene karşı gelişen bağışıklık tepkisine doğru ilerleyen geçişte bir takım olası tetikleyiciler vardır. Bunlar arasında bağırsak enfeksiyonları, tüketilen gluten miktarı ve kalitesi, bağırsak mikrobiyota bileşimi ve bebek beslenme uygulamaları olduğu varsayılmaktadır (4).

Gluten, başlıca gliadin ve glutenin olmak üzere yüzlerce ilişkili ancak farklı proteinlerin karışımından oluşur (3). Glutelin nötral solüsyonda çözülmeyen asit ve alkalide çözülebilen bir form iken; suda çözünmeyip alkolde çözünen form ise prolamin olarak adlandırılır. Bunun dışında gliadin buğday tanesinde bulunan prolamin türüne verilen isimdir. Glutenin toksik etkisi daha çok gliadinden kaynaklanmaktadır. Misır tanesinde glutelin miktarı düşük prolamin miktarı yüksek, pirinç tanesinde ise glutelin miktarı yüksek prolamin 
miktarı düşük olduğu için gluten kompleks yapısı oluşumu gözlenmezken; buğday, arpa, yulaf ve çavdarda prolamin ve glutelin eşit düzeylerde olduğu için ekmek yapımında ekmeğin kabarmasını sağlayan elastik yapı olan gluten kompleksi oluşur (5).

Gliadinin karşılıkları çavdarda hordein, arpada secalin ve yulafta avenindir. Ancak tartışmalı konulardan biri olan yulaf, görece daha az miktarda gluten içermesi sebebiyle 1996'dan sonra bat1 diyetinde serbestler listesine eklenmiştir (3). Ülkemizde ise daha az miktarlarda tüketilmesine rağmen kontaminasyon riski bulunması ve ortak ataları nedeniyle immünolojik çapraz reaktiviteye sahip olacağı düşüncesiyle yasaklı listesinde bulundurulur (5).

Çeşitli belirti ve bulgularla kendini gösterebilen ÇH, çoklu genetik geçiş özelliklidir bir diğer ifade ile multigenetiktir (1). Tüm sistemleri ilgilendiren çok geniş bir belirti yelpazesine sahiptir ve semptomatik gelişebildiği gibi asemptomatik (sessiz) olarak da bulunabilir. Gastrointestinal sistem dışı bulguları atipik olarak isimlendirilir (6). Bir multiorgan hastalığı şeklinde de tanımlanan ÇH'nin etyolojisi multifaktöriyeldir. Çevresel tetikleyicisi ve otoantijeni (enterosite ait doku transglutaminaz enzimi-tTG) bilinen tek otoimmün hastalıktır ve bir diğer önemli özelliği tetikleyicisi olan glutenin diyetten uzaklaştırılmasıyla tam iyileşmenin sağlanıyor olmasıdır (7).

Çölyak hastalığı, çocukluk döneminin en s1k "malabsorpsiyon" sebebi olarak sayılmasına rağmen bebeklik, adölesan veya erişkinlik döneminin herhangi bir zamanında ortaya çıkabilmekte, çıkışından itibaren hayat boyu sürmektedir (8). Günümüzde küreselleşen dünyada değişen beslenme alışkanlıkları nedeniyle ÇH, giderek artan ve tüm ırkları ilgilendiren bir sorun haline gelmektedir. Ülkemizde, 2011 yılında yayınlanan 20190 sağlıklı okul çocuğunun dahil edildiği bir araştırmada ÇH görülme sıklığ $\% 0.47$ olarak açıklanmıştır (9). Çölyak hastalığının artış göstermekte olan prevelansı coğrafi farklılıklara sahip olmakla birlikte; en yüksek sıklık buğdayın beslenme ihtiyacının karşılanmasında önemli bir paya sahip olduğu Türkiye, Avustralya ve Kuzey Amerika gibi ülkelerdedir (8). Tayland, Vietnam gibi pirinç tüketiminin çok olduğu toplumlarda ise oran daha azdir (10). 
Son yıllarda ÇH insidansı gelişmiş ülkelerde artmıştır; bu bulgu gluten dişındaki bir veya daha fazla olası çevresel tetikleyicinin rolüne işaret etmektedir (4). Toplumlar arası ayrımın nedeni kalıtımsal farklılıkların yanı sıra bir takım çevresel etmenlere bağlı olabilir. Glutenle tanışma zamanı ve alınan gluten miktarı, emzirme süresi, geçirilmiş viral enfeksiyonlar ve mamaların muhteviyatı gibi durumlar çevresel etmenler olarak düşünülmektedir (8).

Çölyak hastalığı genel ölüm riskini arttırır, yaşam kalitesini azaltır ve olumsuz ekonomik sonuçları vardır. Gözlemsel bir çalışmadan elde edilen sonuçta gluten için oral tolerans gelişiminin erken yaşlarda başladığ 1 ve bebek beslenmesine gluteni dahil etme şeklinin yatkınlığı olan kişilerde ÇH riskini etkileyebileceği gösterilmektedir. Glutene ilk maruziyetin 4-6 aylıkken olması ÇH riskini azaltmak için bir "fırsat penceresi" olarak ifade edilmektedir (2). Bu öneri İsveç çölyak hastalığ1 epidemisi deneyimine dayandırılmış ve İsveç’te bebekler arasında hastalık insidansındaki büyük artışın nedeni glutenin beslenmeye erken dahil edilmesi ile ilişkilendirilmiştir (11).
İsveç’te, 1985-1995 yı1ları arasında doğan çocuklarda ÇH görülme insidansı, 1996-1997 yıllarında doğan çocuklardan 4 kat fazla bulunmuş ve bu durum “İsveç Salgını” olarak tanımlanmıştır (12).

\section{Çölyak Hastalığı ve Glutensiz Diyet:}

Tek ve sürekli tedavi glutensiz diyettir. Diyete, sadece gluten içeren yiyecekler eklendikten sonra hastalık gelişir (5). Hastaların sağlığ 1 ve yaşam kalitesi glutensiz bir tıbbi beslenme tedavisiyle düzelir. Çocukluk döneminde glutensiz diyete adaptasyonun iyi sağlanması ile intestinal lezyonlarda remisyon, optimal büyüme ve kemik mineral yoğunluğu artışı desteklenir (2). Diyete, biyopsi yapıldıktan ve tanıdan emin olunduktan sonra başlanmalıdır (5). Glutensiz diyet tedavisine iyi bir uyum, ÇH ile ilişkili tüm bulguların azalması yada ortadan kalkması ve spesifik ÇH antikorlarının ve histolojik semptomların normalize olması anlamına gelebilmektedir (9).

Tanısal süreç tamamlanıncaya dek rutin beslenme düzeninde tüketilen miktarlar değiştirilmemeli ve un içerikli besinlerle birlikte makarna, ekmek gibi gluten içeren günlük diyete devam edilmelidir. Özellikle aile üyelerinden herhangi birinde ÇH 
tanısı varlığında, tüm aile düşük gluten içerikli diyet tüketiyor olabileceği için bu gibi durumlar atlanmamalidir (1).

Glutensiz diyet tüketimi olan bireylerde, ÇH şüphesi mevcutsa tanısal süreç başlamadan önce gluten içeren diyete geçilmesi önemlidir. Tarama, test sonuçlarında yanlış negatiflikleri engelleyebilmek adına gluten içeren bir diyet esnasında yapılmalıdır (13). Günümüze dek yayınlanmış hiçbir bilimsel literatür, ölçülebilir serolojik ve/veya barsak mukozası cevabı oluşturmak için alınması gereken minimum gluten miktarını gösteren bir bulguya yer vermemektedir $(2,3,4,6,9)$

Glutenin diyete 6 . ayda ilave edilmesi uzun süredir devam eden bir uygulamadır. "6. ayda gluten” kuralının birçok gelişmiş ülkede kök salmış olmasına rağmen, bebeğin diyetine gluten girişinin optimal zamanlaması net olarak test edilememiştir (4). Birçok klinisyen, kalıtsal hastalık riski olan bebeklerin diyetine gluten eklenmesinin geciktirilmesini tavsiye eder. Zamanlamaya bağlı olarak, bu gecikme ince bağırsak bariyerinin ve mukozal bağışıklık yanıtının olgunlaşmasına izin verebilir.
Çölyak hastalığı otoimmün kökenli olması nedeniyle Tip 1 diabetes mellitus, otoimmün troid gibi bir takım hastalıkların görülme sıklığı sağlıklı popülasyona göre daha yüksektir (5). Bununla birlikte, Tip 1 diyabet için genetik risk taşıyan bebekleri içeren çalışmalar, 4 aydan önce veya 7 ayliktan sonra gluten almaya başlayan bebeklerde Tip 1 diyabet veya ÇH riskinin arttı̆̆ını göstermektedir. $\mathrm{Bu}$ durum 4-7 ay arasında bir zaman aralığında glutenin diyete eklenmesinin tolerans indüksiyonunu kolaylaştırabilecek olduğu görüşünü destekler (4).

\section{Çölyak Hastalığı ve Anne Sütü:}

Anne sütü doğal bir besin olmasının yanı sıra doğumdan itibaren 6 ay bitimine kadar olan dönem için tüm besinsel ihtiyaçlara tek başına cevap verebilen eşsiz bir bileşime sahiptir. Altıncı aydan sonra doğru zamanda başlanan ek besinlerle birlikte 2 yaşın sonuna kadar emzirme sürdürülmelidir. Uygun şekilde başlatılan doğru tamamlayıcı beslenme döneminde emzirmeye devam edilmeli, böylece süt çocuğunun sağlıklı büyümesi ve gelişmesi hedeflenmelidir (14).

Anne sütünün koruyuculuğu ve tahıl türevleri ile bebeğin tanışma yaşı konusu üzerinde yapılan bir 
araştırmada, emzirmenin erken sonlandırılmasının, glutene erken başlamanın veya tanıştırılmanın gecikmesinin hastalık riskini arttırdığ ifade edilmiştir (5).

Bebeklerin 0-6 ay sadece anne sütü ile beslenmeleri, altıncı ayda ek besinlere geçilmesi ve bunu izleyen dönemde tamamlayıcı besinlerle birlikte emzirmenin iki y1l boyunca devam ettirilmesi önerilmektedir (14).

Anne sütünün bebeğin bağışıklık sisteminin şekillenmesinde katkı sağladığı ve gelecekte immün aracılı bir hastalık gelişimini engellemekte anahtar rol oynadığı belirtilmektedir (15). Emzirme süreci devam ederken bebeklerin unlu yiyecekler ile tanışmasının $\mathrm{ÇH}$ gelişme riskini azaltacağı görüşü kanıt düzeyinin düşük bulunması sebebiyle tamamen doğru olarak kabul görmemektedir. Ancak anne sütünün diğer birçok olumlu yönü göz önünde bulundurulduğunda desteklenmesi şarttır (16).

Emzirmenin koruyucu bir rolü olduğu meta-analiz ve sistematik bir derlemede özetlenen birkaç gözlemsel, retrospektif çalışmaya dayanmaktadır. $\mathrm{Bu}$ araştırmalar, emzirmenin hastalığa karşı kalıcı koruma sağlayıp sağlamadığını veya semptomların başlangıcını geciktirip geciktirmediğini netleştirmemiştir $(4,12,17)$.

\section{Çölyak Hastalığı ve Tamamlayıcı Beslenme:}

Tamamlayıcı beslenme süreci, anne sütünün bebeğin nutrisyonel gereksinimini karşılamakta salt yeterli olamadığı dönemde başlamaktadır. Gerek gelişimsel nedenlerle gerek beslenme gereksinimi nedeniyle geçilen tamamlayıcı besinler, anne sütünden aile besinlerine geçişte önemli bir basamaktır (18).

Büyüme ile birlikte hareket yeteneği gün geçtikçe artan bir bebeğe, altıncı aydan sonra sadece anne sütü verilmesi besin ögeleri ve enerji gereksinimlerini tek başına karşılamaya yetmeyeceği için mutlaka tamamlayıcı beslenmeye geçilmelidir (6).

Tamamlayıcı besinlere başlama zamanı ve miktarına dair veriler çoğunlukla subjektiflik içerir; sosyoekonomik ve kültürel bir takım çevresel etmenlere bağlı olarak ve ülkeden ülkeye bazı gıdaların bulunabilirliğinin değişebilmesine göre farklılık göstermekte olduğu ileri sürülmüştür (18). Hollanda ve İsveç gibi ülkelerde 4-6. ay döneminde "alıştırma besinlerine" veya "ufak deneme besinlerine" çoğunlukla başlanırken bazı ülkelerin 
ulusal programlarında tamamlayıcı besinlere başlanma zamanı 6 . ay sonrası olarak önerilmektedir (19).

Tamamlayıc beslenmenin yanı sira emzirme ile çölyak hastalığg riskini değerlendiren çalışmaların sonuçları da kesinlik içermemektedir, çünkü bu çalışmaların çoğu retrospektiftir ve ebeveyn hatırlama yanlılığı (bias) ile ilişkilidir. Hiçbiri randomizasyon içermez veya tüketilen gluten miktarlarını belirtmez. Halen, erken beslenmenin ÇH gelişimi üzerindeki gerçek etkisi tartışmalıdır $(2,6,10-14)$.

\section{Çölyak Hastalığı Riski Açısından Glutenin}

\section{Tamamlayıcı Beslenmeye Eklenme Zamanı:}

Tamamlayıcı beslenmeye başlanan ilk haftalarda yüksek miktarda gluten verilmemesi ve glutene 47 ay arasında (17-26 hafta) başlanması ESPGHAN tarafindan yayınlanan klavuzlarda vurgulanmaktadır. Bebeklere, genetik risk durumu bilinmiyorsa tamamlayıcı olarak gluten eklenebileceği ifade edilmektedir $(2,16) . \mathrm{Bu}$ durum, genetik olarak risk taşıyan bebeklerde glutenle tanıştırmanın geciktirilmesi veya dikkatli olunması şeklinde anlaşılabilir.
Glutenin 4.aydan önce başlanması hastalık riskini arttırmaktadır (19). Glutenle tanışma referansının 4-6 ay arası olarak alındığ ayda glutenle tanışan bebeklerin $\mathrm{ÇH}$ riskinin 23 kat, 6.aydan sonra tanışanların ise 4 kat fazla olduğu belirlenmiştir (6). Özellikle 8.aydan sonra karışık tahıllı ve meyveli kombinasyonlar; alerji, diyabet ve çölyak riskini azaltır. Ancak üçüncü aydan önce verilen gluten çölyak hastalığ 1 riskini arttırmaktadır. Dördüncü aydan sonra anne sütü yanında az miktarda gluten ise bu riski azaltmaktadır (19).

Ülkemizde 2018 y1lı Türkiye Nüfus ve Sağlık Araştırması (TNSA) raporunda, Türkiye'de altı aydan küçük çocukların \%59'unun tek başına anne sütü ile beslenmediği bulunmuştur. 1998 TNSA'daki ortanca emzirme süresi 11,9 ay ile 2018'deki süreden 0-35 aylık çocuklar için 16,7 ay ile yaklaşık beş ay daha kısadır. 10 yıllık bir zaman döneminde emzirilme süresinde yıllar içinde bir artışın söz konusu olduğu görülmüştür. 6-23 ay tahıllı yiyecek tüketimi; emzirilen bebeklerde \%54.8 iken emzirilmeyenlerde \%62.8 ile daha yüksek bir orana sahiptir (20). 
Literatüre dayanarak ESPGHAN 2008 y1lında gluten içeren besinlere başlamanın erken $(<4$ ay, $<17$ hafta) ve geç ( $\geq 7$ ay, 26 hafta) olmasının engellenmesi gerektiğine dikkat çekmiş, emzirme süresince glutenle tanıştırılmasının $\mathrm{ÇH}$, buğday alerjisi ve aynı zamanda Tip 1 diabetes mellitus (DM) olasılığını düşüreceği öngörüsünde bulunmuştur (21). Kuloğlu Z., tarafından da Tip 1 DM'li çocuklarda ÇH sıklığının \%4.5-7.4 olduğu ve otoimmün hastalıkların, IgA eksikliğinin ve bazı genetik sendromların $\mathrm{ÇH}$ ile birlikteliğinin bilindiği vurgulanmaktadır (13).

ESPGHAN 2016 yılına gelindiğinde ise bebeklerin gluten içeren yiyeceklerle tanıştırılmasına yönelik önerisinde ek besine geçilen ilk hafta içerisinde ve bebeklik dönemi boyunca fazla miktarda glutene maruziyetten kaçınılması gerektiğini belirtmiştir. Ayrıca günümüzde halen bebeklik döneminde gluten için optimum tüketim miktarının belirlenmemiş olduğu unutulmamalıdır (21).

Bebeklerde erken beslenme uygulamalarının çölyak hastalığı üzerine etkisini inceleyen bir çalışmada uzun süreli emzirmenin ÇH'nin yaşamın ilk yılında ortaya çıkma oranını düşürdüğü ve emzirme süresinin hastalık gelişmesinde en büyük gösterge olduğu bulunmuştur ( $\mathrm{P}=0.007)$. Gluten tüketmeye dördüncü aydan önce başlayan bebekler ile 4-6 ay arası tüketen bebekler arasında tanı yaşı açısından anlamlı bir fark saptanmamıştır. $\mathrm{Bu}$ çalışmada hastalığın şiddeti üzerine ne emzirmenin ne de glutenle tanışma zamanının bir etkisinin olmadığı ifade edilmiştir. Uzun süreli ve glutenle tanışmadan sonra devam eden emzirmenin klasik ÇH başlangıcını geciktirdiği diğer yandan ne emzirmenin ne de glutenle tanışma zamanının ÇH'nin şiddetini etkilemediği ifade edilmektedir (22).

Norveç Hasta Kayıt Sistemi (NPR) üzerinden 2013 yılında yürütülen bir prospektif cohort çalışmasında glutenle tanışma zamanı ile ( $>6$ ay) uzun süreli devam eden emzirmenin (>12 ay) hastalık riski üzerindeki etkisi araştırılmıştır ve bu durumda olan çocuklarda artmış bir risk görüldüğü ifade edilmiştir (23). Norveç çalışması, sadece emzirmenin koruyucu bir etkisini desteklemekle kalmayarak aynı zamanda 12 aylıktan daha uzun süren emzirme ile ÇH riskinin artması arasında beklenmedik bir ilişkiyi göstermektedir (4).

Tüm bu varsayımlardan yola çıkılarak ÇH'nin olası birincil önlemini araştırmak üzere Avrupa Çok 
Merkezli Çölyak Hastalığını Önleme projesi (PreventCD) başlatılmıştır (24). Son yıllarda yapılmış oldukça geniş kapsamlı bir çalışma olan ve sekiz farklı ülkenin tamamında genetik yatkınlığı olan 950 çocuğun araştırmaya dahil edildiği PreventCD (Prevent Coeliac Disease) projesiyle, emzirme süresince küçük miktarda glutenle tanışmanın gluten intoleransını uyardığı hipotezi araştırılmıştır. Prospektif, randomize, çift kör, plasebo kontrollü bir diyet-müdahale çalışması olarak planlanmıştır. $\mathrm{Bu}$ proje, genetik olarak yatkın 3 yaş altı bebeklerin (en az bir 1. derece aile üyesinde teşhis bulunan) 16 - 24 haftalıkken, tercihen hala emzirilirken küçük miktarlarda glutene maruz bırakılması ile ÇH sıklığının azaltılabileceği hipotezi üzerine kurulmuştur. Çalışma sonucu 2014 yılında yayınlanarak çözüme ilişskin rehberler revize edilmiştir $(2,24)$.

Çölyak Hastalığının bebek beslenme stratejileri yoluyla önlenmesi konulu bu çalışmada glutenle tanışmanın dört aydan daha erken ve yedi aydan daha geç olmaması gerektiği hem erken hem de geç gluten verilmesinin $\mathrm{ÇH}$ riskini arttırdığı, emzirmenin ise hastalık semptomlarının ortaya çıkışını mı geciktirdiği yoksa önlemeye yardımcı mı olduğunun netlik kazanmadığı ifade edilmiştir (25).

Kalıtımsal olarak ÇH'ye yatkın bir çocuk kohortunda 10 yıllık takip sonrasında potansiyel ÇH'nin belirgin ÇH'ye karşı ilerlemesinin değerlendirilmesi amacıyla "Genetik Risk Altındaki Çocuklarda Potansiyel Çölyak Hastalığının Uzun Dönem Sonuçları: Prospektif CELIPREV (The Risk of Celiac Disease and Age at Gluten Introduction) Kohort Çalışması" planlanmıştır. Gluten içeren bir diyeti sürdüren ve genetik olarak ÇH'ye yatkınlığı olan bireylerde hastalık gelişme riskinin uzun vadede çok düşük olduğu sonucuna ulaşılmıştır (26).

Ancak 2015 y1lına gelindiğinde ise aynı araştırmacılar tarafından PREVENTCD ve CELIPREV çalışmalarına atıf yapan yeni bir yayın ile emzirmenin koruyucu rolünde, glutenle tanışma zamanının veya geciktirilmiş gluten tanışmasının destekleyici kanıtlar içermediği ifade edilmiştir. Sadece genetik yatkınlığın en önemli faktör olarak buna sebep olduğu belirtilmiştir (27).

Glutenin geciktirilmesinin ya da emzirmenin, risk altındaki bebekler arasında ÇH riskini değiştirmediği, ancak glutenin beslenmeye daha 
sonra eklenmesinin gecikmiş bir hastalık başlangıcı ile ilişkili olduğu ifade edilmiştir. Ortalama emzirme süresi, ÇH gelişen riskli çocuklar ile bozukluğun gelişmediği riskli çocuklar arasında çok benzer bulunmuştur (sırasıyla 5.6 ve 5.8 ay). Emzirme sirasında gluten verilmesinin koruyucu bir etkisi gözlenmemiştir. Çalışmalara göre yüksek riskli bir HLA (insan lökosit antijeni) genotipinin hastalığın önemli bir belirleyicisi olduğu belirtilmektedir. $(4,6,27)$.

Glutenin verilmesini 12 aya kadar ertelemenin, ÇH gelişme riski üzerinde uzun vadede hiçbir etkisinin olmadığı bulunmuştur. $\mathrm{Bu}$ sonucun, gluten maruziyetini 12 aya kadar ertelemenin güvenli olduğu ancak genetik olarak Tip 1 diyabet riski taşıyan çocuklarda adacık otoimmünitesi riskini önemli ölçüde azaltmadığı bulgusu ile tutarlı olduğu ifade edilmiştir $(4,6)$. Bebek beslenmesi ile çölyak hastalığı riski arasındaki ilişkinin farklı yönlerine 1şık tutan bu çalışmada gluten girişinin ertelenmesinin, potansiyel olarak olumlu iki sonucunun olduğu ifade edilmiştir. Birincisi, hastalığın beyin gibi savunmasız organlar üzerindeki olumsuz etkisini azaltabilecek gluten enteropatisinin gelişimini geciktirmesi; ikincisi, yüksek riskli HLA genotipini taşıyan çocuklar arasında herhangi bir yaşta ÇH otoimmünitesinin önemsiz de olsa yaygınlığını azaltmasıdır (4).

Anne sütündeki anti transglutaminaz antikorları nedeniyle emzirmek faydalı mı yoksa zararlı mı konulu 2017 yılında yayınlanan bir vaka kontrol çalışmasında risk altındaki bebeklerde ne geciktirilmiş gluten tanışmasının ne de emzirmenin çölyak hastalığı riskini değiştirmediği belirtilmektedir (28).

Glutene başlangıç yaşının genetik olarak yatkın çocuklarda ÇH riski ile ilişkili olup olmadığını belirlemek amacıyla yapılan çalışmada ise TEDDY (Gençlerde Diyabetin Çevresel Belirleyicileri) isimli prospektif bir doğum kohort araştırmasından taranan yüksek riskli HLA-genotipli yenidoğan bebekler $(\mathrm{N}=6436)$ Finlandiya, Almanya, İsveç ve ABD'de takip edilmiştir. Bebek beslemesi ile ilgili veriler her üç ayda bir klinik ziyaretlerde toplanmıştır. Glutenle 17 haftadan önce veya 26 haftadan sonra tanışmanın ne genel analizde ne de ülke bazında bir karşılaştırmada tTGA (transglutaminaz otoantikoru) veya ÇH için artmış risk ile ilişkili olmadığı, glutenle ilk tanışma 
zamanının ÇH gelişimi için bağımsız risk faktörü olmadığı belirtilmiştir (29).

İtalyan Pediatrik Gastroenteroloji, Hepatoloji ve Beslenme Derneği (SIGENP) çalışma grubu tarafından ÇH riski ile glutenin bir çocuğun diyetine eklendiği yaş, sütten kesme ve çocuğun erken beslenme düzeni arasındaki ilişkinin belirsiz olduğu ifade edilmektedir (4).

Son zamanlarda yayınlanan girişimsel çalışmaların sonuçları, önceki gözlemsel çalışmaların bulgularını doğrulamamış ve güncel önerileri desteklememiştir. Ne glutene başlama zamanı ne de emzirme genetik olarak yatkın kişilerde ÇH'ye karşı koruma sağlamamaktadır $(15,21,22)$. Bu sebeple, gluten başlangıç yaşının (4 ila 12 ay arasında herhangi bir yerde) ÇH'nin önlenmesi üzerinde etkisi olmadığından, erken beslenme uygulamalarının çocukluk dönemi hastalık gelişimi riski üzerindeki rolü belirsizdir. Ayrıca 6 ay ve daha uzun süreli emzirme, bebek sağllğ 1 üzerindeki olumlu etkileri nedeniyle teşvik edilmelidir. Ancak ÇH'yi önleme bunun bir nedeni olarak kullanılmamalı denilmektedir $(6,27)$.

\section{Çölyak Hastalığı ve Diyetisyenlik Yaklaşımları:}

Çölyak hastalığının tıbbi beslenme tedavisi yaşam boyu sürdürülmesi gereken glutensiz diyettir (30). Glutensiz yaşam, risksiz bir yaşamdır. Glutensiz diyete sıkı bir şekilde uyulmasının ardından hızla iyileşme görülür ancak, gluten yeniden tüketildiğinde hastalık belirtileri bağırsakta ortaya çıkıp şikayetler tekrarlanır. Dengeli bir glutensiz diyet, gluten içermeyen alternatif tahıllar ile birlikte glutensiz özel ürünlerin tüketim kombinasyonu ile oluşturulmalıdır (31).

Çölyak hastalığı olan bireylerin tedavi sürecinde periyodik kontrollerle beslenme ve diyet polikliniği görüşmelerine çağrılıp boy, ağırlık artışı gibi antropometrik verilerin izlenmesi, diyetin uygunluğunun-yeterliliğinin takiplerinin sağlanması ve bu kontroller esnasında glutensiz diyete uyulmasının gerekliliğine dair aile yakınlarına ve hastaya gereken destek, motivasyon ve beslenme eğitiminin verilmesi yararlı bir yaklaşımdır.

Diyette asla kaçamak yapılmaması gerektiği; kesin, net bir tıbbi beslenme tedavisinin uygulanmasinın önemli olduğu ve ufak kaçamakların anında bulgu vermeyebileceği gibi eğitimler diyetisyenler 
tarafindan hastaya aktarılmalıdır. Enerji ve besin ögesi yetersizliği ve dengesizliğinin önlenebilmesi adına doğru planlanmış bir glutensiz diyet şarttır (32).

Hastalar besin ögesi, vitamin ve mineral ihtiyaçlarının alternatif besinlerle karşılanması konusunda bilgilendirilmeli ve her kontrolde diyete uyum yönünden değerlendirilmelidir. Vitamin ve mineral eksikliklerinin tedavisi için glutensiz diyete uyum ile optimal beslenme sağlanmalı ve ihtiyaç halinde besin takviyesi alınmalıdır. Glutensiz ürünlerin posa, folat, kalsiyum, demir, B vitaminleri ve $\mathrm{D}$ vitamini ile zenginleştirilmesi faydalı olacaktır (33).

İlaç muhteviyatları veya besin sanayiinde emülgatörler, stabilizatörler ve raf ömrünü uzatıcı olarak tercih edilebilen ürünlerin bileşimi nedeniyle ÇH teşhisi durumunda iyi bir etiket okuyucusu olunması gerektiği hatırlatılmalıdır.

Glutensiz diyete uyum beraberinde bir takım zorlukları getirmektedir. Hastaların glutensiz özel ürünlere ulaşmada yaşadığı güçlükler ve yüksek fiyatlar nedeniyle bütçelerini aşması diyetten uzaklaşmaya, diyette kaçaklara sebep olmaktadır. Ülkemizde glutensiz ürün erişiminde yaşanan zorluklara ilaveten, bu ürünlerin hatalı raf depolamalarından kaynaklı çapraz bulaş riski konusunda da bireylere bilgilendirme yapılması önemlidir (30).

\section{SONUÇ ve ÖNERILER}

Çevresel ajan olan diyet gluteni tarafından tetiklenen kronik, immün nedenli bir ince bağırsak hasarı olan ÇH riskinden kaçınabilmek için günümüzdeki yaygın öneri glutenin bebeğe erken ( $<4$ ay önce) veya geç ( $\geq 7$ ay geç) verilmesinden kaçınılmasıdır. Diğer bir ifade ile devam eden emzirmenin yanında tahıllara 4-7 ay arasında başlanması ve ilk haftalarda çok yoğun miktarda gluten verilmemesi şeklinde tavsiyeler bulunmaktadir.

- Bebeklerin uzun süreli emzirilmesini önermek için birçok iyi neden olmasına rağmen, son çalışmalar ÇH gelişimi için genetik bir riskleri olup olmadıklarına bakılmaksızın, anne sütünün hastalığa karşı koruyucu bir etki göstermediği ifade edilmektedir.

- Risk grubunda yer alan çocukların gluten ile tanışma zamanının hastalık gelişimi üzerine herhangi bir etkisi yoktur fakat bu sürenin çok geciktirilmemesinde fayda vardır. 
- Güncel yayınlarda hastalığın gelişiminde kalıtımsal yatkınlık ve immünolojik özelliklere ek olarak unlu içeriğe sahip tamamlayıcı besinlere başlama yaşının erken ya da geç olmasının önemli olabileceği görüşünün yanında gluten verilmesi sirasında emzirmenin ÇH gelişimi riskini azaltmayacağını ifade eden görüşler da mevcuttur.

- $\mathrm{Bu}$ nedenle emzirmenin özellikle ilk 4-6 ay arası dönemde önleyici ve koruyucu bir rol oynadığına ve yaşamın ilk aylarından itibaren gluten içeriği yüksek gidalarla beslenmenin ciddi risk oluşturduğuna dair yaygın kabulün yanında günümüz stratejilerinin hastalığ1 önleyip önlemediği ya da sadece semptomların ortaya çıkışını mı geciktirdiği netliğini bir miktar kaybetmiştir.

- Son araştırılan konular arasında, bağırsak mikrobiyotasının ÇH'nin patogenezinde daha önceden bilinenlere kıyasla daha büyük bir rol oynayabileceği dikkati çekmektedir.

- Günümüzde tamamlayıcı beslenme uygulamaları ile anne sütü ve emzirme ilişkisine ek olarak mikrobiyotanın bileşiminin de toleranstan glutene karşı bir bağışıklık tepkisine doğru giden geçişin olası tetikleyicisi olduğu varsayılmaya başlanmıştır. Mirobiyota bileşimi, metabolik profil, aşılama programı ve antibiyotik kullanımı gibi temel çevresel faktörlerin, yaşamın ilk 5 yılında risk altındaki bebeklerde tolerans-immün yanıt dengesini etkileyip etkilemediğini belirlemek için ek çalışmalara ihtiyaç vardır.

- Enfeksiyonlar veya aşılar gibi diğer çevresel faktörlerin rolü ise halen belirsizliğini korumaktadır.

Sonuç olarak çölyak hastalığı ile anne sütü, emzirme ve tamamlayıcı beslenme uygulamaları ilişkisini araştıran çalışmaların günümüzde geldiği nokta önceki sonuçların aksi yönünde bazı çıkarımlara ulaşmış olsa da genetik olarak riskli bireylerin yer aldığı araştırmaların topluma yayılan genellemeler hususunda zayıf kalması nedeniyle çevresel faktörlerin kapsamlı çalışıldığı deneysel araştırmalara ihtiyaç vardır. Daha detaylı bilgilere ulaşılması sonucunda gluten ile tanışma zamanı ve miktarı konusundaki karmaşık ilişkiye dair öneriler netlik kazanacaktır. 


\section{KAYNAKLAR}

1. Husby S, Koletzko S, Korponay-Szabo IR, Mearin ML, Phillips A, Shamir R, et al. European Society for Pediatric Gastroenterology, Hepatology and Nutrition guidelines for the diagnosis of coeliac disease. Journal of Pediatric Gastroenterology and Nutrition. 202070 (1): 141-156

2. Vriezinga, S.L., et al.Randomized Feeding Intervention in Infants at High Risk for Celiac Disease. N Engl J Med 2014; $371 ; 14$

3. Biesiekierski, J. R. What is gluten? Journal of gastroenterology and hepatolog. 2017.32, 78-81.

4. Lionetti, E., et al.Introduction of Gluten, HLA Status, and the Risk of Celiac Disease in Children. Sütten Kesme ve ÇH Riski SIGENP.N Engl J Med 2014; 371: 1295-1303

5. Metin S. Çölyak Hastalığında Nutrisyon. Güncel Gastroenteroloji Dergisi, 2016; 20(3):259-262

6. Şanlıer, N. ve Bolluk, S. Çölyak Hastalığının Önlenmesinde Bebek Beslenmesinin Önemi. Acıbadem Üniversitesi Sağlık Bilimleri Dergisi. ACU Sağlık Bil Derg 2014(1):15-19 Cilt: 5

7. Pinto-Sanchez et al. Gluten Introduction to Infant Feeding and Risk of Celiac Disease: Systematic Review and Meta-Analysis. The Journal of Pediatrics. 2015; Volume 168, Pages 132143.e3

8. Dalgıç, B. Sarı, S. Özcan, B. Baştürk, B. Ensari, A. Eğritaş, O. ve ark. Türk çocuklarında çölyak hastalığı ile ilişkili olası etmen ve belirtilerin değerlendirilmesi. Turk Arch Ped 2011;46:323-330.

9. Emiroğlu, H.H ve ark. Çölyak Hastalığı Tanısı ile İzlenen Çocuklarda Klinik Özellikler: Tek Merkez Sonuçları. J Contemp Med 2017; 7(4): 333-339

10. Dimitri Poddighe, Marzhan Rakhimzhanova,Yelena Marchenko, Carlo Catassi. Pediatric Celiac Disease in Central and East Asia: Current Knowledge and Prevalence. Medicina $2019,55,11$

11. Ludvigsson, Jonas F.and Green, Peter H.R. The Missing Environmental Factor in Celiac Disease. N Engl J Med 2014; 371:1341-1343

12. A Ivarsson, L A Persson, L Nyström, H Ascher, B Cavell, L Danielsson, A Dannaeus, T Lindberg, B Lindquist, L Stenhammar, O Hernell. Epidemic of coeliac disease in Swedish children.Acta Paediatr. 2000 Feb;89(2):165-71.

13. Kuloğlu, Z. Çölyak Hastalığı. Türkiye Çocuk Hastalıkları Dergisi Turkish Journal of Pediatric Disease. 2014;8(2) : 105111

14. Topal, S., Çınar, N., Altınkaynak, S. Süt Çocukluğu Döneminde Beslenme. DÜ Sağlık Bil Enst Derg Journal of Duzce University Health Sciences Institute / J DU Health Sci Inst 2016; 6 (1): 63-70

15. Guandalini S. The approach to Celiac Disease in children. Int $\mathbf{J}$ Pediatr Adolesc Med. 2017 Sep; 4(3): 124-127.

16. Szajewska H, Shamir R, Mearin L, et al. Gluten Introduction and the Risk of Coeliac Disease: A Position Paper by the European Society for Pediatric Gastroenterology, Hepatology, and Nutrition. J Pediatr Gastroenterol Nutr 2016;62(3):50713.

17. Ivarsson A, Hernell O, Stenlund H, Persson LA. Breast-feeding protects against celiac disease. Am J Clin Nutr 2002 ; 75:5 914 $-921$

18. Pekcan, G. Tamamlayıcı Beslenme: Avrupa Pediatrik Gastroenteroloji, Hepatoloji ve Beslenme (ESPHGAN) Birliği Komitesi Görüş Raporu. Bes Diy Derg 2018;46(1):1-6

19. Yazıcı, B. Tamamlayıcı Beslenme. Klinik Tıp Pediatri Dergisi 2018;10(1): 7-16

20. Hacettepe Üniversitesi Nüfus Etütleri Enstitüsü. Türkiye Nüfus ve Sağlık Araştırması, TNSA, 2018. T.C Cumhurbaşkanlığ 1 Strateji ve Bütçe Başkanlığı ve TÜBİTAK. Syf :143-146
21. Silano, M., Agostoni, C., Guandalini, S. Effect of the timing of gluten introduction on the development of celiac disease. World J Gastroenterol 2010 April 28; 16(16): 1939-1942

22. Radlovic, Nedeljko P., et al. Influence of Early Feeding Practices on Celiac Disease in Infants Clinical Sciences Croat Med J. 2010; 51: 417-22

23. Stordal, K. et al. Early Feeding and Risk of Celiac Disease in a Prospective Birth Cohort. PEDIATRICS Volume 132, Number 5, November 2013.

24. PreventCD: European scientific research project to prevent coeliac disease. [Internet]. 2021 [cited 2021, Ağustos 30]. Available from https://preventceliacdisease.com/en/

25. Chmielewska, A. et al.Celiac Disease - Prevention Strategies through Early Infant Nutrition. Evidence-Based Research in Pediatric Nutrition. World Rev Nutr Diet. Basel, Karger, 2013, vol 108, pp 91-97

26. Lionetti, E., et al. Long-Term Outcome of Potential Celiac Disease in Genetically at-Risk Children: The Prospective CELIPREV Cohort Study. J Clin Med. 20195 Şub; 8 (2). 186

27. Chmielewska, A. et al. Primary Prevention of Celiac Disease: Environmental Factors with a Focus on Early Nutrition. Ann Nutr Metab 2015;67(suppl 2):43-50

28. Zingone, F. et al. Case report With antitransglutaminase antibodies in the breast milk, is breastfeeding beneficial or harmful? Celiac Center, Gastrointestinal Unit, AOU S. Nutrition 41 (2017) 126-127

29. Aronsson, C., A. et al. Age at Gluten Introduction and Risk of Celiac Disease. TEDDY STUDY GROUP PEDIATRICS. Volume 135, Number 2, February 2015

30. Yıldırım, E. (2020). Çölyak hastalığ1 ve glutensiz beslenme, Genel Sağlık Bilimleri Dergisi, 2(3), 175- 187

31. Ulusoy H.G., Rakıcıoğlu N. (2019) Glutensiz Diyetin Sağlık Üzerine Etkileri. Bes Diy Derg, 47(2), 87-92

32. Türkiye Cumhuriyeti Sağlık Bakanlığı Halk Sağlığı Genel Müdürlüğü Sağliklı Beslenme ve Hareketli Hayat Daire Başkanlığı. (2019). Çölyak Hastalığında Aile Hekimleri İçin Tanı, Tedavi ve İzlem Rehberi, Sağlık Bakanlığı Yayın No: 1111, Ankara

33. Tunçer, E., Yabancı Ayhan, N. Çölyak Hastalığında Mikro Besin Ögesi Eksiklikleri Ve Beslenme Önerileri. BANÜ Sağlık Bilimleri ve Araştırmaları Dergisi. (2021). 3(1), 29-38. 